This PDF is a selection from a published volume from the National Bureau of Economic Research

Volume Title: Monetary Policy under Very Low Inflation in the Pacific Rim, NBER-EASE, Volume 15

Volume Author/Editor: Takatoshi Ito and Andrew K. Rose, editors

Volume Publisher: University of Chicago Press

Volume ISBN: 0-226-37897-7

Volume URL: http://www.nber.org/books/ito_06-1

Conference Date: June 25-27, 2004

Publication Date: September 2006

Title: Stock Market Liquidity and the Macroeconomy: Evidence from Japan

Author: Woon Gyu Choi, David Cook

URL: http://www.nber.org/chapters/c10146 


\title{
Stock Market Liquidity and the Macroeconomy \\ Evidence from Japan
}

\author{
Woon Gyu Choi and David Cook
}

\subsection{Introduction}

In the early 1990s, Japanese equity prices fell drastically from heights that are now considered the effects of a stock market bubble. During the remainder of the decade, the value of the stock market stabilized at much lower values. Here, we examine the link between the liquidity of the Japanese stock market and the macroeconomy in a period of prolonged deflation, slow growth, and near-zero interest rates.

Recent research has shown that the liquidity of major world financial markets substantially varied over time and that the unpredictability of market liquidity is an important source of risk for investors. In this chapter, we document a large and persistent decline in Japanese stock market liquidity during the 1990s. In illiquid stock markets, investors are unable to sell large amounts of shares without a sharp decline in the price of the shares. We show that the impact of stock trading on share prices rose substantially after the collapse of the bubble. In addition, the volatility of liquidity shocks to the stock market increased dramatically.

A number of factors have led to a decline in asset-market liquidity during the late 1990s. First, Japanese financial intermediaries experienced a substantial deterioration in their balance sheets. If market makers and

Woon Gyu Choi is a senior economist at the International Monetary Fund. David Cook is an associate professor of economics at the Hong Kong University of Science and Technology.

The views expressed in this paper are those of the authors and do not necessarily represent those of the IMF or IMF policy. We thank Tim Chue, Burkhard Drees, Shinichi Fukuda, Takatoshi Ito, Charles F. Kramer, Andrew Rose, Makoto Saito, Sunil Sharma, Ling Hui Tan, and participants at the NBER East Asian Seminar on Economics meetings for comments. David Cook thanks the Research Grants Council of Hong Kong for financial assistance (Project No. HKUST6291/03H) and Hao Li for valuable research work. 
other investors faced credit constraints, this may have reduced their ability to take advantage of high returns by providing liquidity to an illiquid market. Second, during much of this period, Japan was operating in a deflationary environment in which savers were able to earn real returns simply by holding money. This may have reduced their incentives to take speculative risks by providing liquidity to the market. Third, adverse shocks to liquidity in the world and East Asian financial markets potentially increased the exposure of Japanese firms. At the microstructure level, the Tokyo Stock Exchange implements a continuous auction-based order system in the late 1990s, dispensing with market makers (Tokyo Stock Exchange 2003). ${ }^{1}$

We consider some channels through which financial market liquidity shocks may affect the macroeconomy. Naturally, a rise in equity risk tends to raise the cost of capital of firms through the cost of financing channel. Using cross-sectional data, we find that exposure to liquidity risk is an important determinant of investment. Another channel pertains to the effects of shocks on the portfolio of assets. Kiyotaki and Moore (2001) construct a theory in which liquid assets are held primarily as a hedge against the illiquidity of real assets. A rise in money held for financial liquidity may reduce money available for transactions. In an economy with nominal rigidities, an increase in money demand can have real effects on the economy. Nagayasu (2003) finds evidence of a structural break in money demand in Japan during the crisis. Indeed there is a sharp decline in the velocity of money in the late 1990s. We find, using time-series data, that shocks to financial market liquidity have effects on the economy, which are similar to textbook effects of money demand shocks.

In measuring stock market liquidity, we closely follow Pastor and Stambaugh's (2003) measure of United States equity market liquidity. They measure liquidity by the degree to which the quantity of stocks traded affects the market price of stocks. In a liquid market, large sales of stocks can be made without substantially changing the price of the stocks. In an illiquid market, however, they can have an adverse impact on stock prices. Amihud and Mendelson (1986) is an early study of the relationship between market liquidity and stock returns. Campbell, Grossman, and Wang (1993) construct a model in which risk-averse market makers require a premium to buy large quantities of stock. Chordia, Sarkar, and Subrahmanyam (2002) find that aggregate liquidity fluctuations in the United States affect both bond and stock markets and are correlated with monetary policy. Stahel (2004) finds that global liquidity shocks affect stock markets in both the United States and Japan. Hamao, Mei, and Xu (2003)

1. Buy and sell orders are matched first according to price (highest buy to lowest sell offer) and second by time of placement. Also, important features of the Tokyo Stock Exchange include the intraday price limit rule and limit-order trading - for the institutional features of trading, see, for example, Ahn et al. (2002). 
find a dramatic decrease in trading volumes in the Japanese stock market after the bubble burst.

Section 8.2 describes the technique for measuring stock market liquidity and some of the time-series properties of market liquidity shocks. We find that, during the 1990s, stock market liquidity fell, and the volatility of liquidity shocks increased. Moreover, the exposure of individual firms' equity shares to liquidity shocks rose during the same period. Section 8.3 presents some firm-level cross-sectional determinants of liquidity risk and the real impact of exposures to liquidity risk. We find that the liquidity of individual corporate balance sheets predicts how exposed their shares will be to liquidity shocks. Moreover, exposures to liquidity shocks help determine the capital growth and sales growth of firms during the crisis. In Section 8.4 , we examine the dynamic interaction between stock market liquidity and the macroeconomy using vector autoregressions (VARs). An examination of money markets suggests that a decline in stock market liquidity leads to a rise in the demand for real money balances. Section 8.5 concludes. The data used are described in an appendix.

\subsection{Measure of Liquidity Risk}

\subsubsection{Measuring Stock Market Liquidity}

In measuring Japanese aggregate stock market liquidity, we closely follow Pastor and Stambaugh's (2003) measure for the United States equity markets. For a group of Japanese common shares indexed by $k$, we estimate the effect of order flows on excess daily returns for each month from January 1975 to December 2001. Using time-series ordinary least squares (OLS), we estimate the following equation:

$$
r_{k, d, t}^{x s}=\theta_{k, t}^{0}+\theta_{k, t}^{1} \cdot r_{k, d-1, t}+\theta_{k, t}^{2} \cdot \operatorname{sign}\left(r_{k, d-1, t}^{x s}\right) \cdot \operatorname{vol}_{k, d-1, t}+\varepsilon_{k, d, t},
$$

where $r_{k, d, t}$ is the return on the stock of company $k$ on day $d$ of month $t$. Define $r_{d, t}^{M K T}$ as the equal-weighted return on Japanese stocks in the Pacific Capital Markets (PACAP) database (see the appendix). The excess return $r_{k, d, t}^{x s}=r_{k, d, t}-r_{d, t}^{M K T}$ is measured as the difference between the return on stock $k$ and the market return. The $\operatorname{sign}\left(r_{k, d-1, t}^{x s}\right)$ variable is equal to 1 when lagged excess returns are positive and equal to -1 when lagged excess returns are negative. We define $v o l_{k, d, t}$ as the value of shares traded, measured in billions of yen. The signing of the trading volume is meant to distinguish whether trades are driven by selling pressure from investors or by buying pressure. When investors are selling shares in a company to market makers or other short-term liquidity providers, such as speculators, excess returns on that company should be negative. When investors are buying from market makers, excess returns should be positive. The lagged return is included to capture inertia effects that are not volume related. 
The parameter $\theta_{k, t}^{2}$ measures the degree to which sales affect returns and thus might be thought of as a measure of liquidity in that particular market. One would expect $\theta_{k, t}^{2}$ to be negative in general and more negative when liquidity is lower. This idea is rooted in Campbell, Grossman, and Wang's model (1993) in which a large value of shares traded generates reversals in returns in illiquid markets. ${ }^{2}$ In their model, risk-averse market makers demand higher than expected returns to buy or sell a large volume of shares. When there are large sales at day $d-1$, the market makers offer a relatively low price, generating negative excess returns in period $d-1$ and predicting relatively high returns in the subsequent period. Under this theory, trading volume should be associated with return reversals, if the stock is not perfectly liquid. Technically, the Tokyo Stock Exchange (Tokyo Stock Exchange 2003) does not operate on a system in which specified market makers are responsible for the trading of individual stocks. The Campbell, Grossman, and Wang theory can apply more generally to a case in which there are a limited number of investors willing and able to engage in shortterm speculation in individual stocks. It is therefore interesting to see whether the Pastor and Stambaugh (2003) model captures some features of market liquidity in a market without market makers.

We estimate $\theta_{k, t}^{2}$ for each stock-month for which there are at least nine usable observations during the month and for which both the previous month and the subsequent month have at least nine usable observations. To obtain a consistent sample of firms during the 1990s, we choose from the PACAP database a set of 828 nonfinancial firms for which we are able to estimate $\theta_{k, t}^{2}$ for at least 140 of the 144 months between January 1990 and December 2001, and for which we can obtain balance-sheet data (from the same source) in years 1990, 1995, and 2000. To avoid contaminating the sample with the results of buyouts or bankruptcies, we exclude firms whose equity permanently ceases trading at some point.

Panel A of figure 8.1 shows the number of shares, $N_{t}$, for which we are able to estimate the effect of trading value on returns for each month for the period between January 1975 and December 2001. We begin with approximately 500 different shares, a number that grows with time. By construction, the number of firms after 1989 is approximately constant. (Other panels of the figure will be discussed later.)

\subsubsection{Descriptive Statistics of the Aggregate Stock Market}

Table 8.1 also shows some properties of the shares of our sample in comparison with a broader index of stocks from PACAP. The equal-weighted average monthly return (excluding dividends) for shares in the overall sample of firms is about 0.8 percent per month; in our smaller sample, the

2. Chao and Hueng (forthcoming) show that return reversals are a prevalent phenomenon of the Japanese stock market. 
A

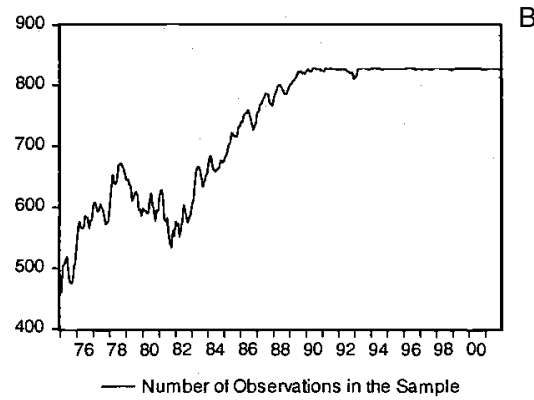

C

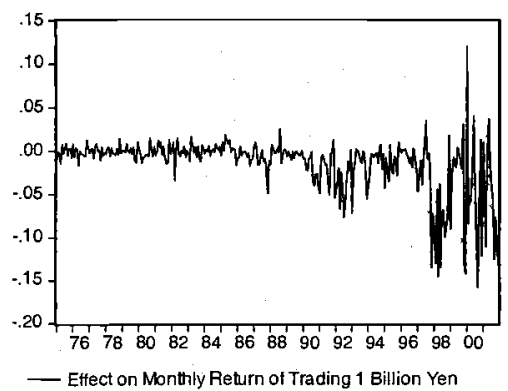

B

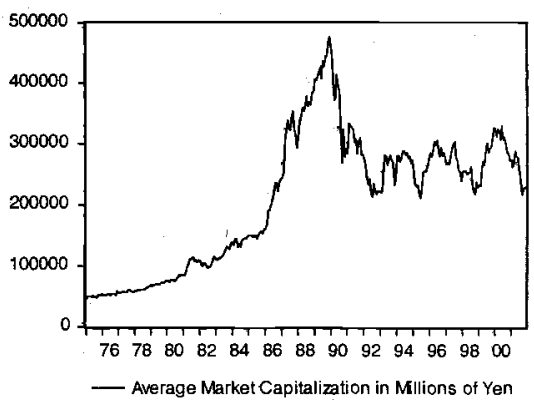

D

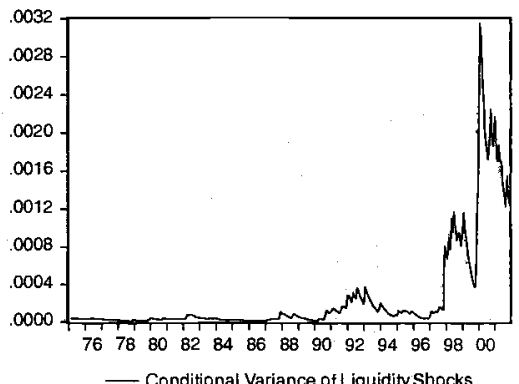

$\mathrm{E}$

Market Liquidity 1996-2001

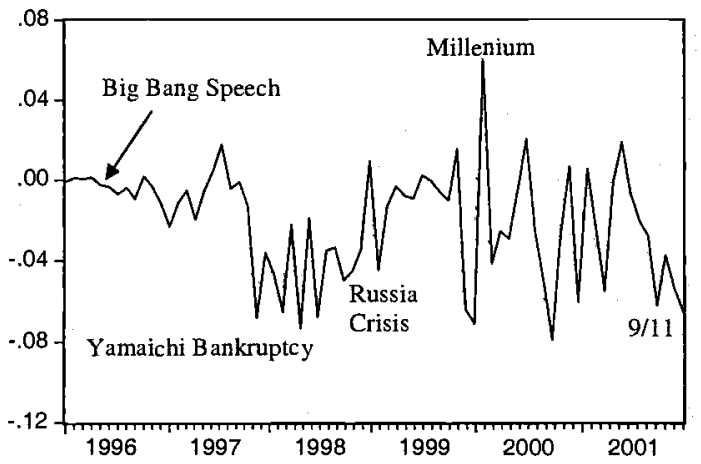

Fig. 8.1 Time-series liquidity measures

Notes: The figure shows the details of aggregate market liquidity. Panels A and B show the details of the sample of firms including the number of firms in the sample observed in any period and the market capitalization of those firms. Panel $\mathrm{C}$ shows the aggregate market liquidity measure, $L I Q$, which essentially is the average cost, in terms of returns, of trading 1 billion of 2001 yen. Panel D shows the conditional heteroscedasticity of shocks to an AR(2) process in $L I Q$. Panel $\mathrm{E}$ is a closeup of panel $\mathrm{C}$ with the indication of episodic dates. 
Table 8.1

Descriptive statistics of stock market aggregates (\%)

\begin{tabular}{lccc}
\hline & $\begin{array}{c}\text { Entire period } \\
\text { (January, 1975- } \\
\text { December 2001) }\end{array}$ & $\begin{array}{c}\text { Early 1990s } \\
\text { (January, 1990- } \\
\text { December, 1995) }\end{array}$ & $\begin{array}{c}\text { Late 1990s } \\
\text { (January, 1996- } \\
\text { December, 2001) }\end{array}$ \\
\hline $\begin{array}{l}\text { Mean return } \\
\quad \text { PACAP index } r^{M K T}\end{array}$ & 0.80 & -0.37 & -0.55 \\
$\quad \begin{array}{l}\text { Our sample } \\
\text { Standard deviation of market return }\end{array}$ & 0.61 & -0.28 & -0.49 \\
$\quad$ PACAP index & 5.90 & 8.04 & 6.97 \\
$\quad$ Our sample & 5.74 & 8.67 & 7.38 \\
Monthly turnover & & & \\
$\quad$ TOPIX & 4.38 & 2.19 & 3.22 \\
$\quad$ Our sample & 5.08 & 3.38 & 3.62 \\
\hline
\end{tabular}

Notes: This table characterizes some of the statistical properties of time series from the Japanese stock markets. We compute the mean and standard deviation of returns from an equalweighted index calculated by PACAP and those from an equal-weighted average of our sample of firms. We also compare the turnover (ratio of monthly value traded to market capitalization) for the Tokyo Stock Exchange and our sample of firms.

average return is slightly smaller at 0.6 percent per month. We will focus on two subperiods: the early 1990s (January 1990-December 1995) and the late 1990s (January 1996-December 2001). In both the early and late 1990s, mean returns are negative and slightly lower for the large sample than for our narrower sample. This may not be surprising since our sample drops those shares that stop trading at some point during the 1990s. In all subperiods, the standard deviation of the equal-weighted monthly returns in our sample is similar to that in the PACAP sample. The volatility of returns increases during the 1990s in both samples and is largest during the early 1990s.

\subsubsection{Dissecting Changes in Market Turnover}

To access stock market liquidity, we compare the average monthly turnover of the shares of our sample, relative to the turnover of the stocks measured in the Topix index of the Tokyo Stock Exchange. Turnover is defined as the value of shares traded in a month as percentage of end-ofperiod market capitalization (bottom rows of table 8.1). In the whole period, about 4 percent of the value of shares in the Topix index is traded in the average month. Our sample is slightly more liquid with about 5 percent of the value traded. While turnover is slightly higher in our sample than the Topix sample in both subperiods, it is lower in the early and late 1990s than in the entire period in both samples.

Given the overall decline in market liquidity, we look more closely at which investors left the market. Figure 8.2 shows the path, from 1988 to 2001, of average monthly purchases of stocks (relative to overall market 


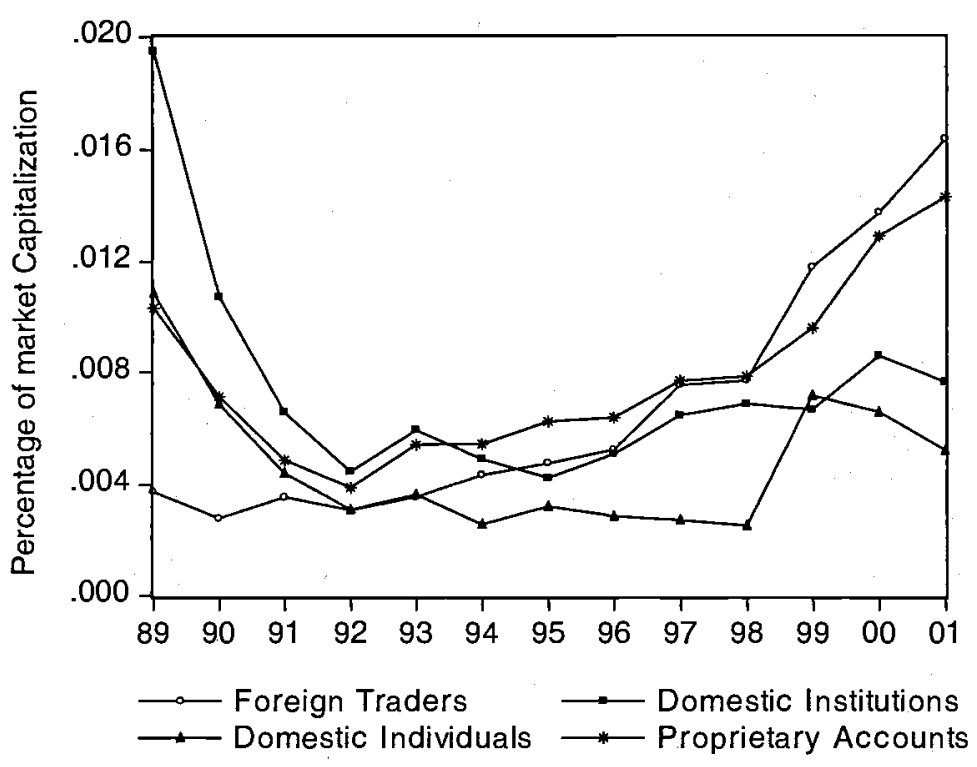

\section{Fig. 8.2 Purchases of shares by type of investor}

Notes: The figure shows Tokyo Stock Exchange data on the quantity of shares purchased by four types of investors relative to aggregate market capitalization. Data reported are yearly averages of monthly data.

capitalization) by investors trading for their proprietary accounts and by three other types of investors trading through brokerages. The three types include domestic individuals, domestic financial institutions, and foreign traders. All trading is reported relative to the aggregate market capitalization. Purchases by foreign traders grew throughout the period, while trading by all three types of domestic investors initially declined following the burst of the stock market bubble. Over the course of the 1990s, trading on proprietary accounts recovered. However, trading through brokerages by individuals and institutions persistently declined during the first half of the period. In particular, by the end of the period the share traded by domestic institutions had fallen to less than half of its initial level. ${ }^{3}$

\subsubsection{Properties of the Liquidity Measure}

The aggregate measure of the market value, $m_{t}$, of the shares for which we are able to calculate $\theta_{k, t}^{2}$ is given by

$$
m_{t}=\sum_{k=1}^{N_{t}} \text { mktcap }_{k, t} \text {, }
$$

3. Wang (2003) shows that institutional participation is a significant determinant of market liquidity in the United States. 
where mktcap $_{k, t}$ is the end-of-month market capitalization of stock $k$ in month $t$, and $N_{t}$ is the number of shares in month $t$. Panel A of figure 8.1 shows the average market capitalization $m_{t} / N_{t}$ during each period. In the mid-1970s, the average firm in the sample had a market capitalization of approximately 45 billion yen. During the 1970s and 1980s, average market capitalization grew rapidly to a peak of nearly 500 billion yen in late 1989 before falling rapidly to a level near 200 billion yen. During the 1990s, average market capitalization fluctuated between 200 and 300 billion yen.

Chordia, Roll, and Subrahmanyan (2002) find that average market liquidity in the United States (as measured by bid-ask spreads) shows substantial variation over time. Following Pastor and Stambaugh (2003), we measure average market liquidity, $L I Q_{t}$, as follows:

$$
L I Q_{t}=\frac{m_{t}}{m_{\mathrm{Dec}, 2001}} \cdot \frac{\sum_{k=1}^{N_{t}} \theta_{k, t}^{2}}{N_{t}} .
$$

We average the liquidity parameter across the firms with usable observations in a particular month $t$. The parameter measures the effect of a billion yen trading on stock returns. To reflect the growth in size of the stock market over time, the average of $\theta_{k, t}^{2}$ across firms is multiplied by the ratio of the sum of the market capitalization of the firms to the market capitalization at a fixed date, December 2001.

Panel $\mathrm{C}$ of figure 8.1 shows the time path of $L I Q_{t}$. The aggregate market liquidity is negative in most of the time, suggesting - in accordance with theory - that heavy trading results in return reversals due to illiquidity. Further, aggregate market liquidity varies substantially. Table 8.2 (part A) shows that the mean level of liquidity is -0.014 so that sales of 1 billion yen (roughly in 2001 yen) result in expected returns of 1.4 percent in a month. The market became less liquid over time, and the average level of $L I Q_{t}$ fell to -0.02 in the early $1990 \mathrm{~s}$ and fell further to below -0.04 by the late $1990 \mathrm{~s}$, approximately twice the entire period mean. A simple Chow breakpoint test at January 1996 rejects the stability of the mean at any reasonable critical value. However, an Adjusted Dickey-Fuller test with twelve lags rejects the hypothesis of a unit root at the 1 percent critical value (regardless of whether a deterministic trend term is included). Although Pastor and Stambaugh (2003) document substantial and persistent variations in the U.S. equity market, such variations do not involve so prolonged a liquidity drought as observed in the Japanese market in the late 1990s.

Panel E of figure 8.1 shows more closely the time series of aggregate market liquidity over the period 1996-2001 (essentially a close-up of panel C of figure 8.1). Over this period, market liquidity seems to reflect a response to both national and international events. Perhaps coincidentally, in the periods following the November 1996 announcement of the "Big Bang" market 


\begin{tabular}{lccc}
\hline & $\begin{array}{c}\text { Entire period } \\
\text { (January, 1975- } \\
\text { December, 2001) }\end{array}$ & $\begin{array}{c}\text { Early 1990s } \\
\text { (January, 1990- } \\
\text { December, 1995) }\end{array}$ & $\begin{array}{c}\text { Late 1990s } \\
\text { (January, 1996- } \\
\text { December, 2001) }\end{array}$ \\
\hline \multicolumn{4}{c}{ A. Liquidity measure } \\
Mean & -0.0143 & -0.0200 & -0.0401 \\
Shock volatility & 0.0147 & 0.0102 & 0.0274 \\
Correlation w/ PACAP index & 0.268 & 0.424 & 0.252 \\
Covariance w/ PACAP index & 0.000226 & 0.000342 & 0.000425 \\
Mean & B. Liquidity beta & & \\
Standard deviation & - & 1.573 & 0.536 \\
Percent firms with & - & 1.150 & 0.567 \\
$\quad$ significant $t$-statistics & & 32.6 & 27.3 \\
\hline
\end{tabular}

Notes: Part A characterizes the mean and standard deviation of our measure of market liquidity, $L I Q$, as well as its correlation and covariance with the PACAP equal-weighted index. Part B characterizes the cross-sectional distribution of the partial betas from regressions of individual stock returns on the aggregate index and liquidity shocks. The characterization includes mean and cross-section standard deviation of the coefficient on liquidity shocks as well as the percentage of firms with significant $t$-statistics based on Newey and West's heteroscedasticity-autocorrelation consistent standard errors.

liberalization, there was a persistent decline in market liquidity, followed by a recovery over the summer of 1997. However, in November 1997, market liquidity suddenly plunged to a level dramatically lower than that observed in any prior period. This episode coincides with major turmoil in the Japanese financial system (as well as the East Asian financial crisis) since a number of intermediaries including the fourth largest securities firm (Yamaichi Securities) and one of the city banks (Hokkaido Takushoku) were forced into bankruptcy. This low level of liquidity persisted through 1998, including a negative spike in September coincident with the Russian crisis and the collapse of Long-Term Capital Management (LTCM). ${ }^{4}$

Liquidity recovered to more normal levels through 1999 . However, a new persistent decline in liquidity occurred in November 1999 and was punctuated by a number of periods in which liquidity increased rapidly but temporarily. In one of these periods, January 2000, liquidity reached a level much higher than previously observed. During the turn of the millennium period, the level of bank reserves held at the Bank of Japan also spiked.

We observe another sharp decline in liquidity after September 2001, de-

4. Crises can be internationally transmitted through diverse channels. In particular, a crisis in one market causes institutional investors to sell liquid assets in other markets to meet regulator requirements (a forced-portfolio recomposition effect). Forbes (2000), using firm-level cross-country data, shows that individual company's stock market returns are affected by global trading liquidity during the East Asian and Russian crises through a forced-portfolio recomposition. 
spite that Japan has undergone reforms to liberalize its financial markets in ways that may allow the additional participation of external investors and institutions. Persaud (2000), however, argues that the common use of modern risk-management practices leads to herding behavior that may reduce market liquidity despite a large number of market participants. Also, such a decline in liquidity might be associated with heightened perceptions of risk after the $9 / 11$ terrorist attack.

\subsubsection{Robust Measures}

We also examine some alternative measures of liquidity. Figure 8.3 (panel A) shows the pattern of $\Sigma_{k}^{N_{t}} \theta_{k, t}^{2} / N_{t}$, which is unadjusted for changes in market capitalization over time. According to this measure, the impact of trading a billion yen worth of shares from the mid- to the late seventies was indeed very large and comparable with more recent periods. However, during the 1980s, return reversals associated with large stock sales became

A

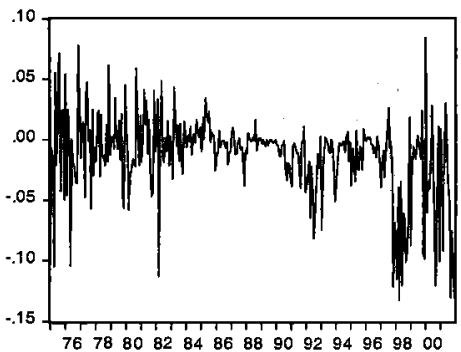

— Liquidity (Unadjusted for Changes in Aggregate Market Capitalization)

C

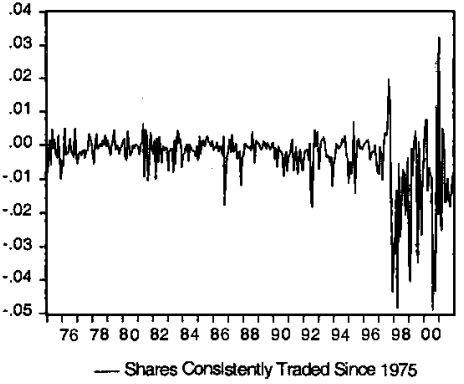

B

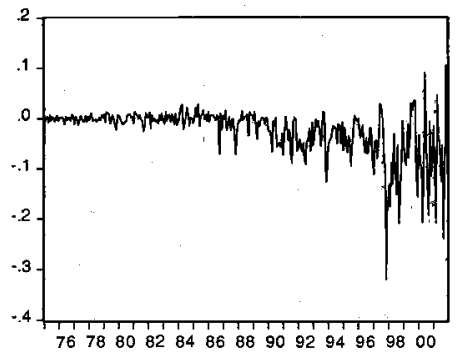

- Broadest Number of Shares

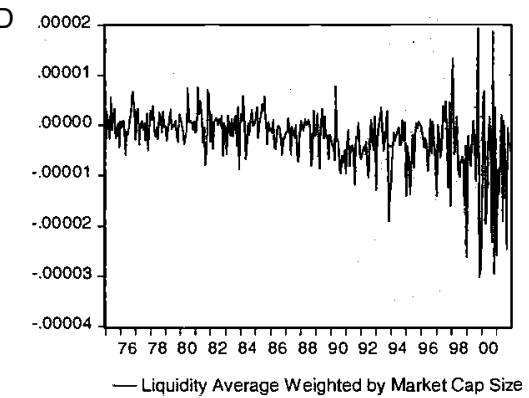

Fig. 8.3 Alternative liquidity measures

Notes: Panel A shows the average liquidity in terms of return of trading a billion yen in current currency units (i.e., unadjusted for changes in aggregate market capitalization). Panel B shows the average liquidity using a sample of all available firms including those that joined or left the sample during the 1990s. Panel C shows the average liquidity of a group of firms that were observed for the entire twenty-seven year period between 1975 and 2001. Panel D shows the weighted (by market capitalization) average liquidity of the sample. 
much smaller, beginning to rise dramatically again in the 1990s just as in the benchmark series, $L I Q$.

Panels B and $\mathrm{C}$ show alternative measures of $L I Q_{t}$ for different sets of firms. Panel B pertains to the set of firms that includes all of the nonfinancial firms available in which an estimate of $\theta_{k, t}^{2}$ is available in that time period. The number of firms ranges from about 500 in 1975 to about 1,400 by 2001 . The measure of liquidity with this broad set of firms shows a similar pattern, compared to our benchmark measure of liquidity. During the 1970s and 1980s, stock market liquidity was relatively high. During the 1990s, the aggregate liquidity began to fall. After 1997, stock market liquidity on average dropped dramatically and the volatility of liquidity rose.

Panel $\mathrm{C}$ depicts a liquidity measure defined by the average $\theta_{k, t}^{2}$ (weighted across time by aggregate market capitalization) of a group of approximately 370 firms for which we are able to measure liquidity for at least 320 out of the 324 months in the years between 1975 and 2001. This measure of liquidity shows again a similar path with a fall in liquidity in the 1990s and a more dramatic decline after 1997 along with an increase in volatility of liquidity. The average level of liquidity of this group of more established companies was higher than that of the broader sample.

Finally, panel D displays a weighted average of $\theta_{k, t}^{2}$ with the weight for each firm being the end-of-month market capitalization. This measure shows the same pattern as the other measures with a marked drop in liquidity in the 1990s. In the weighted average, the size of return reversals is smaller, indicating that big-cap stocks are more liquid.

\subsubsection{Measuring of Shocks to Market Liquidity}

A measure of innovations to liquidity is the adjusted average of innovations to the liquidity of each firm:

$$
\Delta L I Q_{t}=\frac{m_{t}}{m_{\mathrm{Jan}, 1990}} \cdot \frac{\sum^{N_{t}}\left(\theta_{k, t}^{2}-\theta_{k, t-1}^{2}\right)}{N_{t}} .
$$

Aggregate liquidity shocks are estimated as innovations to the following dynamic process:

$$
\Delta L I Q_{t}=\beta_{0}+\beta_{1} \cdot \Delta L I Q_{t-1}+\beta_{2} \cdot L I Q_{t-1}+\omega_{t},
$$

where the predicted change in liquidity depends on the lagged change and the deviation of the lagged level from its long-run mean (impounded in $\beta_{0}$ ). The fitted residuals are a measure of liquidity shocks:

$$
\text { lshock }{ }_{t}=\hat{\omega}_{t} \text {. }
$$

Table 8.2 (part A) shows that the average standard deviation of liquidity shocks varies from period to period. The standard deviation for the entire sample is about 0.015 . However, much of this volatility is concentrated in 
the late $1990 \mathrm{~s}$, where the standard deviation is above 0.027 as compared with that of 0.010 in the early 1990s.

We conduct a Breusch-Pagan LM test for conditional heteroscedasticity on the residuals and reject conditional homoscedasticity with a $p$-value of less than $10^{-4}$ using any number of lags between one and twelve. We estimate a $\operatorname{GARCH}(1,1)$ process for lshock $k_{t}$ :

$$
\begin{gathered}
\sigma_{t}^{2}=0.000+0.851 \sigma_{t-1}^{2}+0.190 \text { lshock }_{t-1}^{2} . \\
(0.000)(0.025) \quad(0.030)
\end{gathered}
$$

(standard errors in parentheses)

Panel D of figure 8.1 shows the fitted value of the conditional variance of the shock. The volatility of the liquidity shock increased sharply during the early 1990s. Such a sharp rise was followed by a much larger rise in conditional variance in 1998 and, finally, an even larger jump in 2000-2001.

We calculate the correlation between the PACAP equal-weighted stock return, $r_{t}^{M K T}$, and $l s h o c k_{t}$ (part A of table 8.2). The correlation in the entire period is about 0.27 . During the early 1990s, the correlation between liquidity shocks and aggregate stock returns was as high as 0.42 and fell to 0.25 in the late 1990s. However, despite the fall in correlation, the overall exposure of firms' shares to aggregate liquidity shocks rose over the decade because of the increased variance of shocks. The covariance between the aggregate return index and the liquidity shock was about 20 percent larger in the late 1990s sample than in the early 1990s sample.

\subsubsection{Liquidity Risk and Asset Pricing}

To check if there is some relationship between liquidity risk exposure and the average returns, we estimate a partial liquidity beta, $\beta_{k, p e r i o d}^{\text {liquid }}$, by regressing the monthly excess return on the liquidity shock over the period January 1990-December 1995.

$$
r_{k, t}-i_{t-1}=\alpha+\beta_{k, \text { period }}^{M K T} \cdot\left(r_{t}^{M K T}-i_{t-1}\right)+\beta_{k, \text { period }}^{\text {liquid }} \cdot l \text { shock } k_{t}+e_{k, t},
$$

where period is equal to the early 1990s or the late 1990s, $r_{k, t}$ is the monthly return on stock $k$, and $i_{t}$ is the collateralized overnight call money rate.

The average $\beta_{k, 90-95}^{\text {liquid }}$ across firms is about 1.6 while the average $\beta_{k, 96-01}^{\text {liquid }}$ is slightly greater than 0.5 (part B of table 8.2). Note that the median is very close to the mean for both figures. Although a given shock on returns has a smaller effect in the later period, the overall rise in the volatility of the liquidity shock indicates that the partial covariance of the shock (measured as the product of $\beta_{k, \text { period }}^{\text {liquid }}$ and the variance of $l s h o c k_{t}$ ) is higher in the later period. Using Newey-West corrected, heteroscedasticity-autocorrelation consistent standard errors, we find that the percentages of firms that have significant exposures to the liquidity shocks at the 5 percent level in two subperiods are not much different: about 33 percent of the firms have liquidity 
Table 8.3

Banking risk measure, liquidity shocks, and market returns

\begin{tabular}{lcccc}
\hline & lshock & $r^{M K T}$ & $r^{M K T}$ & $r^{M K T}$ \\
\hline lshock & & $0.636^{* * *}$ & & $0.458^{* *}$ \\
Sjpnprem & $(3.35)$ & & $(2.13)$ \\
& $-0.056^{* * *}$ & & $-0.270^{* * *}$ & $-0.247^{* * *}$ \\
Adjusted $R^{2}$ & $(-2.67)$ & & $(-4.29)$ & $(-3.53)$ \\
& 0.021 & 0.052 & 0.141 & 0.161 \\
\hline
\end{tabular}

Notes: Regression results with the PACAP equal-weighted stock index on liquidity shocks and the change in the Japan premium. The Japan premium, as a measure of banking risk, is defined as the spread between the interest rate paid on dollar borrowing in the Japanese interbank market and the rate paid on dollars in London. The coefficient estimates are reported with Newey-West's heteroscedasticity-autocorrelation consistent $t$-values (in parentheses).

$* * *$ Significant at the 1 percent level.

**Significant at the 5 percent level.

beta's which are significantly different from zero in the first subperiod, while approximately 27 percent of the firms do in the second subperiod.

\subsubsection{Banking Risk and Liquidity Shocks}

We examine the connection between liquidity shocks and banking risk. Liquidity shocks may be the result of credit rationing, which prevents speculators from borrowing money that could be used to buy stocks. We can measure banking risk by the premium that Japanese banks pay to borrow from abroad. In the late 1990s, Japanese banks paid a premium to borrow in euro markets. Ito and Harada (2000) show that this premium is connected to incidents related to both the failures of Japanese financial firms and the excess returns on banking stocks. The Bank of Japan (BOJ) collects data on the Japan premium from 1997. The Japan premium is persistently high during 1997 and 1998, a period when stock market liquidity is also persistently low. ${ }^{5}$

Table 8.3 summarizes the regression results for the relationship between liquidity shocks, banking risk, and market returns. The estimated coefficient (along with Newey-West corrected standard errors) from a regression of liquidity shocks, lshock, on the first difference in the Japan premium, $\Delta$ jpnprem, suggests that increases in the Japan premium are associated with negative shocks to stock market liquidity (table 8.3, column 1). This association is significant at the 1 percent level. However, the adjusted $R^{2}$ from the regression is less than 0.03 , suggesting much of the variation in liquidity shocks is not directly caused by the Japan premium.

To examine how liquidity shocks and the Japan premium are associated

5. Banks whose credit ratings deteriorate upon adverse aggregate shocks may drop out of the international interbank market. Such dropouts are positively correlated with country risk and thus reflected in the measured Japan premium. 
with innovations to stock returns, we regress the PACAP equal-weighted market return, $r^{M K T}$, on 1shock and $\triangle$ jpnprem over the period January 1997-December 2001. Positive innovations in liquidity are associated with relatively high stock returns (column 2). The association is statistically significant in each case at the 1 percent level. Increases in the Japan premium are significantly (at the 1 percent level) negatively associated with stock returns (column 3). Also, when we include both variables (column 4), changes in the Japan premium are still significant at the 1 percent level. The effect of the liquidity shock remains significant for the equal-weighted return at the 5 percent level, even with the inclusion of the Japan premium.

\subsection{Cross-Sectional Evidence on Market Liquidity and Growth}

\subsubsection{Firm-Level Variables and Descriptive Statistics}

From PACAP, we extract additional firm-level variables that we consider as factors to explain cross-sectional exposure to liquidity risk. Descriptive statistics are reported in table 8.4. Additional information on the data used in the chapter is provided in the appendix.

First, a large percentage of shares of the firms in our sample are owned either by financial institutions or by corporations. Shares with these kinds of cross-holdings may be less liquid. We construct a variable: percentage of stocks held by banks or corporate sector is the number of shares owned by financial institutions plus shares owned by other businesses divided by the total number of shares in 1995. In 1995, approximately two-thirds of the shares of the mean and median firm are held by banks and other corporations.

Firms with high liquidity needs may be especially vulnerable to aggregate liquidity shocks. We construct a variable to measure short-term debt at the firm level: short-term loans to asset ratio is the measure of short-term loans includes accounts and notes payable, short-term loans and paper (due within one year), as well as the current portion of long-term bonds and loans which are due within the year. Short-term loans are normalized by dividing by total assets in 1995 . These liabilities constitute approximately 30 percent of assets for the mean and median firm, though the number ranges between 0 and nearly 95 percent.

To control for overall leverage, we include other kinds of liabilities: other liabilities to asset ratio indicates the sum of all other liabilities relative to total assets in 1995. Other types of liabilities are approximately 30 percent of assets for the mean and median firm and are on average equal in size to short-term liabilities.

If a firm has more liquid assets, it will be less exposed to liquidity shocks. However, financially weak firms that do not have access to financial markets will fear financial strains caused by insufficient reserves of liquidity and thus try to hold more liquidity. Empirical studies with U.S. firm-level 
Descriptive statistics of firm-level variables

\begin{tabular}{lccc}
\hline Variable & Mean (SD) & Median & [Min, Max] \\
\hline Percent of stocks held by banks or corporate sector & 0.650 & & \\
& $(0.115)$ & 0.661 & {$[0.086,0.921]$} \\
Short-term debt to asset ratio & 0.304 & & \\
& $(0.17)$ & 0.280 & {$[0.000,0.942]$} \\
Other liabilities to asset ratio & 0.292 & & \\
& $(0.146)$ & 0.276 & {$[0.016,0.964]$} \\
Liquid assets to assets ratio & 0.308 & & \\
& $(0.181)$ & 0.272 & {$[0.019,0.986]$} \\
Log of assets & 11.990 & & \\
& $(1.279)$ & 11.862 & {$[8.666,16.44]$} \\
Financial value to book assets & 1.471 & & \\
& $(0.397)$ & 1.393 & {$[0.780,6.042]$} \\
Return on equity & 0.018 & & \\
& $(0.152)$ & 0.034 & {$[-2.859,0.460]$} \\
Growth in net fixed assets (in log difference) & 0.037 & & \\
End of 1995 to end of 2001 & $(0.419)$ & 0.030 & {$[-3.573,1.696]$} \\
Growth in sales (in log difference) & -0.056 & & \\
End of 1995 to end of 2001 & $(0.306)$ & -0.041 & {$[-2.961,1.237]$} \\
\hline
\end{tabular}

Notes: The table summarizes the descriptive statistics for balance sheet data from PACAP for the period 1995-2001. We also report the growth in fixed assets and sales between 1995 and 2001.

data (Opler et al. 1999; Choi and Kim 2001; Hubbard, Kuttner, and Palia 2002) suggest that high-information-cost firms hold comparatively larger cash reserves than do other firms. ${ }^{6}$ Thus, controlling for the size and quality of firms, we examine if firms with more liquid assets are less exposed to liquidity shocks. We construct a variable which measures firms' liquidity positions: liquid assets to assets ratio is the currency, bank deposits, and marketable securities held by the firm relative to total assets in 1995. About 30 percent of the average firms' assets are liquid. Naturally, this constitutes a large range.

Since liquidity shocks may be less important for large firms, which have better access to financial markets, than for small firms, we also include an asset variable as a proxy of firm size. Assets denotes the logarithm of the total assets (measured in millions of yen).

In addition, we include some additional balance-sheet measures to control for the overall quality of the firm. Financial to book value is the sum of total liabilities plus market capitalization divided by total assets in 1995 . This measures the cost of purchasing the firm outright relative to the ac-

6. Almeida, Campello, and Weisbach (2004) suggest that financially weaker firms' liquidity position is more sensitive to cash-flow shocks, compared to financially stronger firms. This reflects that financially weak firms strive to accumulate reserves of liquidity to hedge against liquidity risk while financially strong firms can raise funds from financial market in the event of financial strains. 
counting cost valuation of assets, which is considered as a proxy of Tobin's $q$-ratio. Return on equity indicates net income divided by book equity value in 1995. The typical financial-to-book value in the sample is approximately 1.4. The average return on equity in 1997 was approximately 4 percent but the range is extremely large. Further, PACAP categorizes firms by sector at the approximately one- or two-digit level. The appendix lists the sectors and the number of firms in our sample that fall into these shares.

\subsubsection{Determinants of the Liquidity Premium}

To access the determinants of the liquidity exposure of individual firms during the liquidity-trap period, we regress the partial liquidity beta, $\beta_{k, 96-01}^{\text {liquid }}$, which is obtained from estimating equation (4) for January 1996December 2001, on our firm-level variables. We scale all coefficients by multiplying each by the ratio of the cross-sectional standard deviation of that variable and dividing by the standard deviation of the dependent variable, $\beta_{k, 96-01}^{\text {liquid }}$. The results are reported in table 8.5 (column 1), along with heteroscedasticity-consistent $t$-statistics.

In general, we find evidence on the link between firms' exposures to liquidity shocks and liquidity in their equity markets or balance sheets. Indicators of equity-market liquidity are associated with less exposure to liquidity shocks. We find that large firms (in terms of assets) have less exposure to liquidity shocks than small firms, and this is significant at the 10 percent critical value. Firms whose shares are owned in large part by financial institutions, nonfinancial corporations, or the government also have relatively high-risk exposure, though this is marginally insignificant at the 10 percent critical value ( $p$-value $=0.102$ ).

Perhaps more interestingly, firms with more liquid balance sheets are less exposed to liquidity shocks, whereas firms with more short-term debt are more exposed to the shocks. A one-standard-deviation increase in shortterm debt is significantly associated (at the 1 percent level) with an increase in liquidity exposure equal to 14.3 percent of a standard deviation. By comparison, a one-standard-deviation increase in longer-term liabilities relative to assets is associated with an increase in liquidity exposure of 5 percent of a standard deviation. This association, however, is not significant at even the 10 percent level. Further, firms with large holdings of liquid assets are less sensitive to liquidity shocks. A one-standard-deviation increase in the liquid assets to assets ratio will reduce partial liquidity exposure by 8 percent of a standard error: this relationship is significant at the 5 percent level. The positive link between corporate balance-sheet liquidity and stock market liquidity perhaps indicates that stock market liquidity shocks occur simultaneously with broader shocks to liquidity in the economy including credit markets.

Higher quality firms have less exposure to liquidity shocks. Firms with high financial value relative to book value and firms that earn high profits 


\begin{tabular}{lccc}
\hline Firm Characteristics & $\begin{array}{c}\text { Partial Liquidity } \\
\text { Beta } \beta_{k, 96-01}^{\text {iquid }}\end{array}$ & $\begin{array}{c}\text { Percent growth in } \\
\text { net fixed assets }\end{array}$ & $\begin{array}{c}\text { Percent growth } \\
\text { in sales }\end{array}$ \\
\hline Partial liquidity beta: $\beta_{k, 96-01}^{\text {iquid }}$ & & $-0.130^{* * *}$ & $-0.144^{* * *}$ \\
Percent of stocks held by banks or & 0.061 & $(-2.61)$ & $(-4.89)$ \\
$\quad$ corporate sector & $(1.64)$ & 0.020 & 0.015 \\
Short-term debt to asset ratio & $0.143^{* * *}$ & -0.052 & $(0.55)$ \\
& $(2.77)$ & $(-0.90)$ & $-0.288^{* * *}$ \\
Other liabilities to asset ratio & 0.050 & -0.076 & $(-6.34)$ \\
& $(0.93)$ & $(-1.49)$ & $-0.093^{* *}$ \\
Liquid assets to assets ratio & $-0.083^{* *}$ & 0.002 & $-0.28)$ \\
& $(-2.04)$ & $(0.05)$ & $\left(-2.076^{* *}\right.$ \\
Log of assets & $-0.079^{*}$ & -0.029 & -0.024 \\
& $(-1.89)$ & $(-0.63)$ & $(-0.68)$ \\
Financial value to book assets & $-0.083^{*}$ & 0.081 & $0.082^{* *}$ \\
& $(-1.85)$ & $(1.25)$ & $(2.20)$ \\
Return on equity & $-0.115^{* *}$ & 0.077 & $0.123^{*}$ \\
& $(-2.49)$ & $(1.12)$ & $(1.80)$ \\
Industry dummies & Yes & Yes & Yes \\
No. of observations & 774 & 773 & 772 \\
$R^{2}$ & 0.167 & 0.084 & 0.272 \\
\hline
\end{tabular}

Notes: The table reports the coefficient estimates of the regressions of measures of exposure to liquidity risk and performance on firm characteristics. All variables have been scaled by their cross-sectional standard deviation so that the coefficient represents the impact (as a share of one standard deviation of the left-hand side variable) of a one-standard-deviation increase in each right-hand side variable. Also reported are heteroscedasticity consistent $t$-statistics.

$* * *$ Significant at the 1 percent level.

**Significant at the 5 percent level.

*Significant at the 10 percent level.

relative to book equity have significantly less exposure to liquidity shocks. These relationships are statistically significant at the 10 percent and 5 percent critical value, respectively. Overall, the regression has an $R^{2}$ of about 17 percent.

\subsubsection{Liquidity Exposure and Growth}

To examine the relationship between liquidity exposure and firm growth, we first measure the growth of a firm in terms of capital investment. Growth in net fixed assets is the logarithm of the ratio of net fixed assets in 2000 to net fixed assets in 1995. Over five years from 1995 to 2001, our sample firms grew at 3.7 percent (an annual growth of about 0.7 percent) in net fixed assets. The cross-sectional variation of fixed-asset growth is large with a standard deviation of almost 40 percent.

We also measure real growth in sales. The variable growth in sales is the logarithm of sales in 2000 relative to sales in 1995. Sales declined during the 
period by almost -1 percent on annual average. Again, there is large crosssectional variation in this measure with a standard deviation of over 30 percent.

In table 8.5 (columns 2 and 3), we regress measures of firm growth on liquidity exposure and other firm-level characteristics (as well as some industry dummies). The measure of liquidity exposure is the partial liquidity beta from the late 1990 s period, $\beta_{k, 96-01}^{\text {liquid }}$. The additional firm characteristics are those listed in the previous section. We find that firms that have high liquidity exposure also have statistically significantly (at the 1 percent critical value) slower capital growth. One standard deviation higher in liquidity exposure is associated with 13 percent of a standard deviation decline in capital growth (which is approximately 1 percent lower fixed-investment growth per year). None of the other firm-level characteristics are significant at even the 10 percent critical value.

Firms with high liquidity exposures also tend to have lower sales growth. A one-standard-deviation increase in liquidity exposure is statistically significantly associated (at the 1 percent critical value) with a 15 percent of standard deviation decrease in sales growth (approximately 1 percent lower annual growth in sales). Variables related to market liquidity, such as size and shares cross held, are not significant. However, overall high leverage levels and, especially, high short-term debt are associated with slow sales growth. A one-standard-deviation increase in the short-term debt to asset ratio is significantly associated (at the 1 percent critical value) with a near 30 percent of a standard deviation lower level of sales growth (approximately 3 percent annual lower sales growth). Other liabilities relative to assets are also significantly associated with slow sales growth, though the effect is smaller quantitatively. Interestingly, firms with a high liquid assets to total assets ratio in 1995 have statistically significantly (at the 5 percent critical value) slower subsequent sales growth. This result perhaps reflects that holding liquid assets to hedge against liquidity risk is costly and that such a precautionary liquidity holding may postpone or hinder investment and production for sales. A high market-to-book valuation of assets ratio significantly (at the 5 percent level) predicts subsequent sales growth, and a high return on equity in 1995 also significantly (at the 10 percent level) predicts subsequent sales growth.

\subsection{Time-Series Evidence on Market Liquidity and the Macroeconomy: Vector Autoregression (VAR)}

Monetary assets are part of larger portfolios of assets. Agents may hold more liquid assets as a hedge when the liquidity risk of interest- or dividend-paying assets rises. In Kiyotaki and Moore (2001), money is held entirely as a hedge against the illiquidity of real assets. An increase in money demand might lead to less liquidity available for the purchase of goods 
and, as in standard IS-LM analysis, lead to a decline in economic activity. Thus, one may propose that a negative shock to market liquidity increases money demand and affects adversely economic activity.

To assess this proposition, we estimate a dynamic system with a VAR with terms for real shocks, money-demand shocks, and money-supply shocks during the post-bubble period (1990-2001). We use an economic activity/production index, $y_{t}$, for all sectors of the economy (excepting agriculture) as a measure of real activity. Ueda (1993) argues that Japanese monetary policy targets the call money rate, and Miyao $(1996,2002)$ describes the call money rate as the operating target of the Bank of Japan during the period under consideration. We include the uncollateralized overnight call money rate, call. We use broad real-money balances as a proxy for real-money demand. Specifically, the variable, $m p_{t}$, is the logarithm of the ratio of M2 plus CDs-which Ito (1994) reports as the most commonly used broad money aggregate for Japan - divided by the core Consumer Price Index (CPI) (i.e., CPI not including food and energy). Sekine (1998) argues that financial wealth is a determinant of money demand. We include the log of the Topix stock market index, topix, as a proxy for wealth and to control for the effects of stock market return shocks on market liquidity. This may be important as Bayoumi (2001) has shown that shocks to asset prices have substantial real effects on the Japanese economy during this period.

Since the stock market does not display much in the way of secular growth during the post-bubble period, we measure the level of liquidity as the simple average of the response of returns to signed trading volume:

$$
\text { liquidity }_{t}=\sum_{k=1}^{N_{t}} \frac{\theta_{k, t}}{N_{t}}
$$

We do not multiply this liquidity measure by the aggregate market capitalization that may have macroeconomic effects separate from financial liquidity. The time series for liquidity is shown in the first panel of figure 8.3.

We first conduct Adjusted Dickey-Fuller (ADF) tests on each of the variables to assess for unit roots. Using a specification with four lags and including a trend term, we are unable to reject the null hypothesis of a unit root at the 10 percent level for any of the variables with the exception of liquidity, for which the null hypothesis is rejected at any reasonable critical value. Using the Johansen trace statistic in a specification with four lags and a trend term, we are unable to reject the hypothesis that $y, m p$, or call is cointegrated with topix. We therefore estimate the VAR in a level specification.

We estimate a VAR in [ $y$, call, $m p$, liquidity, topix] with twelve lags, a trend term, and a dummy variable for January 2000 , the millennium period with the anomalously large, positive liquidity realization. The Akaike Information Criterion indicates a second order VAR. However, this strikes us 
as too few lags to capture the dynamics of the monthly system. ${ }^{7}$ Instead, we estimate the VAR with twelve lags, which may be fairly typical for the VAR estimation with monthly data.

We identify shocks to the system using the Choleski decomposition, interpreting them as, in order: real output shocks, money-supply shocks, money-demand shocks, liquidity shocks, and stock-price shocks. Ordering the variables in this way, [ $y$, call, $m p$, liquidity, topix], implies a number of identifying assumptions about the short-run dynamics of the model. We assume each of the shocks could have immediate effects on the price of the stock market. In particular, this ordering implies that innovations in the aggregate price of stocks have no immediate impact on stock market liquidity. However, we do allow market liquidity to respond immediately to all macroeconomic shocks. Following Miyao (2002), we treat exogenous innovations in the call money rate as monetary-policy shocks and allow the call money rate to respond immediately to real output shocks. Also, we allow money demand to respond immediately to output and the interest rate. However, real output responds only with a lag to monetary-policy shocks.

Figure 8.4 displays all of the impulse responses along with two standarderror bands. However, we concentrate on discussing the effects of liquidity shocks on the macroeconomic variables and the effects of various shocks on stock market liquidity. We find that liquidity shocks significantly affect macroeconomic variables. Liquidity shocks affect output in the real economy, but the impact of stock market liquidity on the economic activity index is small and short-lived. A one-standard-deviation increase in liquidity results in an initial increase in output of about 0.2 percent. After one period, the increase in output is not statistically significant at even the 10 percent level. Liquidity shocks never explain more than 7 percent of variation in $y$ at any frequency.

Liquidity shocks have persistent and statistically significant impacts on real balances. A positive shock to stock market liquidity leads to a reduction in the demand for more liquid real balances. Indeed, variance decomposition shows that liquidity shocks explain more than 16 percent of the variation in real balances at a frequency of eighteen months. Liquidity shocks have macroeconomic effects which are consistent with persistent money-demand shocks. A positive liquidity shock also leads to a statistically significant decline in (nominal) interest rates, consistent with the reduced money demand after the shock. However, the effects of liquidity shocks on asset markets themselves seem more transitory. Liquidity shocks have very short-lived effects on the stock market index, topix, reverting to mean after a couple of periods.

7. In particular, a very low-order VAR suggests that liquidity shocks have fairly large and persistent effects on output and real balances. In such a low-order VAR, macroeconomic shocks have insignificant effects on liquidity. 

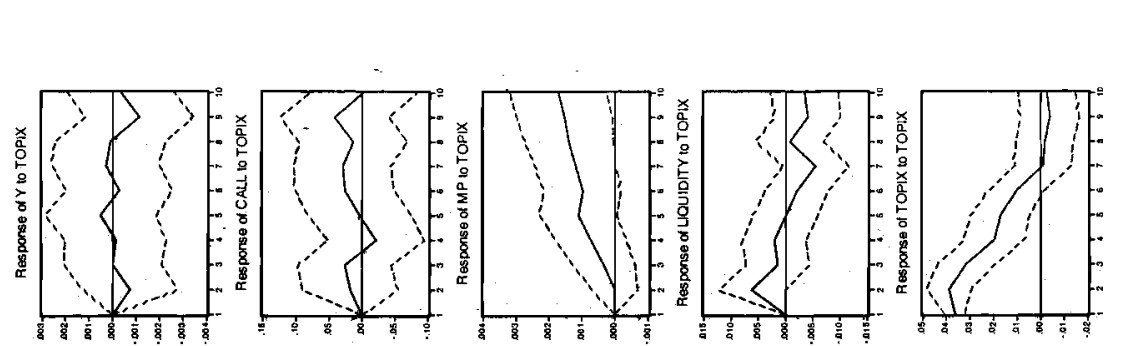

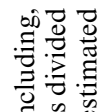
$\approx 0.0$

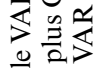
急旅 象

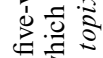
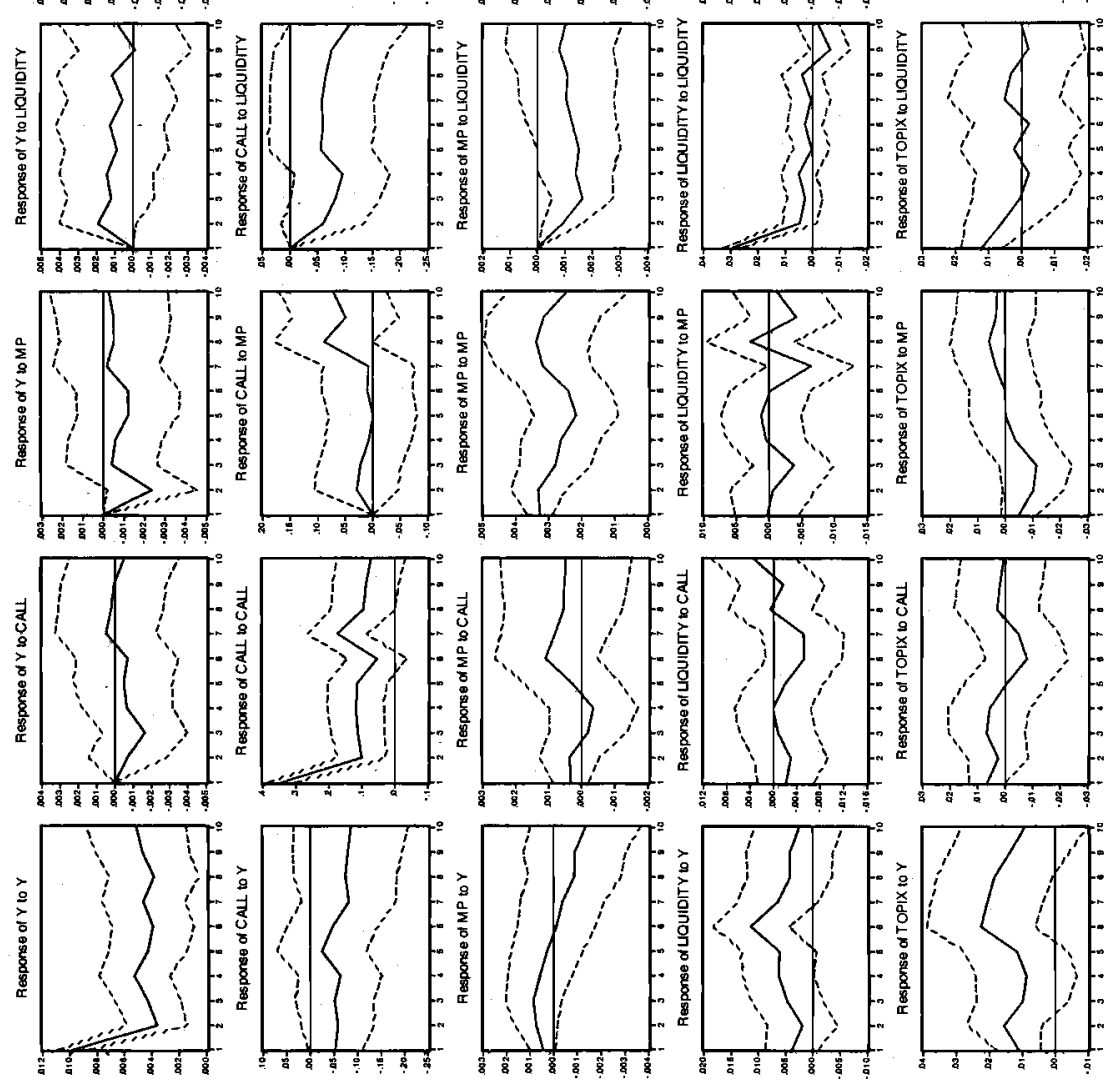
Next, we find that market liquidity is significantly affected by shocks to output and topix but not by shocks to money-market variables, call rates, and real balances. Shocks to topix have a short-lived impact on stock market liquidity, suggesting that a rise in the stock price index attracts liquidity to the stock market at least temporarily. Shocks to economic activity also have significant impacts on stock market liquidity. A positive innovation in $y$ leads to a persistent increase in topix and an increase in stock market liquidity that persists for about six months. At the eighteen month frequency, about 20 percent of the variation in stock market liquidity comes from shocks to $y$. However, neither shocks to call rates nor shocks to real balances have significant effects on stock market liquidity, while liquidity shocks significantly affect both call rates and real balances: in essence, the liquidity shocks could be thought of as general liquidity preference shocks which feed into money and asset markets.

We are also interested in the response of the nominal money supply to stock market liquidity shocks. To look at the response of narrow money, we define mbase as the natural log of the monetary base; to look at broad money, we define $m 2$ as the log of M2 plus CDs. We estimate VARs in $[y$, call, mbase, liquidity, topix] and [ $y$, call, m2, liquidity, topix] with twelve lags, a trend term, and a millennium dummy. Figure 8.5 depicts the impulse responses of the monetary aggregates to a one standard-deviation shock along with two standard-error bands. There seems to be a qualitative difference. The amount of banks' reserves held after a positive liquidity shock declines sharply and immediately. However, after just one period, the supply of reserves returns to the preshock level. By contrast, the positive liquidity shock leads to a reduction in the demand for M2 that occurs much more slowly but more persistently. Interpreted as a persistent decline

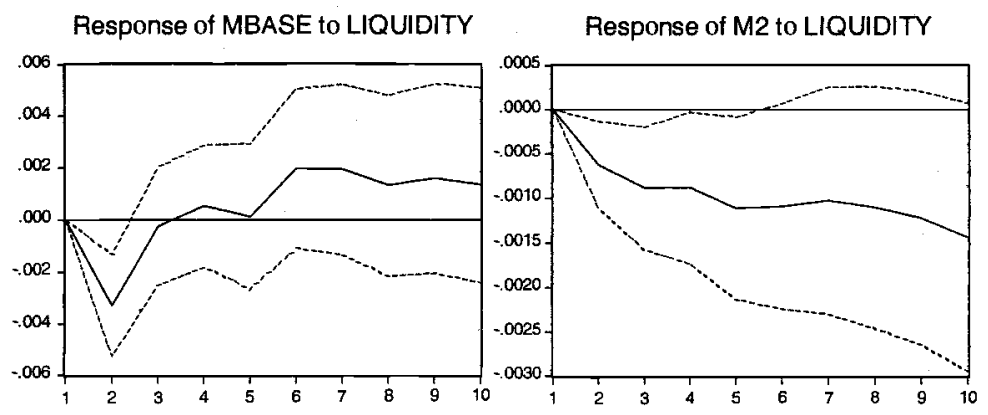

Fig. 8.5 Money and interest rate responses

Notes: The figure shows the responses (along with two standard-error bands) of two monetary aggregates to identified stock market liquidity shocks. The monetary aggregates are the monetary base, mbase, and M2 plus CDs, $m 2$. Shocks are identified using VARs with twelve lags, a trend, and a millennium dummy. 
in money demand that occurs due to a decrease in asset-market liquidity risk, which is not fully accommodated by a reduction in the monetary base, this could explain why the interest rates in interbank lending markets fall persistently following a liquidity shock.

\subsection{Conclusions}

We find evidence that during the recent deflationary period, Japanese equity markets were highly illiquid and subject to increasingly volatile liquidity shocks. Our intention in this chapter is to show some of the causes of this decline in liquidity as well as some of the interactions between stock market liquidity and the macroeconomy.

Financial market evidence suggests that these liquidity shocks affected the equity returns of firms during the slump that followed the bursting of Japan's late-1980s bubble. We find cross-sectional evidence that firms with illiquid balance sheets and illiquid markets for their equity were more exposed to these shocks and that this exposure was a predictor of the performance of the firms during this period. We interpret the high exposure to equity liquidity shocks of firms with high short-term debt as indicating that the liquidity shocks to the stock market were also correlated with liquidity shocks in broader financial markets, including credit markets. This interpretation is supported by time-series evidence that liquidity shocks have even more persistent effects on money demand than on equity market prices.

Using aggregate market liquidity, we find evidence that liquidity shocks in the Japanese stock market are associated with some macroeconomic events. Large declines in liquidity occurred simultaneously with international financial shocks, such as those that occurred in September 1998 and September 2001. Exogenous liquidity shocks seem to have a persistent negative effect on money demand and interest rates, as well as some short-term effects on output. Time-series evidence also shows that the large initial declines in liquidity occurred simultaneously with a wave of bankruptcies of Japanese financial intermediaries, including financial firms. Statistically, the Japan premium (i.e., the extra cost of short-term borrowing imposed on Japanese banks) is strongly associated with stock market liquidity. In general, exogenous negative-business-cycle shocks reduced stock market liquidity. Stabilizing aggregate demand in the face of such a liquidity shock may require the monetary authority to reduce interest rates. Since 1999, Japanese monetary policy has been characterized by zero interest rates, the lower bound that prevents the full accommodation of liquidity shocks. The policy of quantitative easing undertaken by the Bank of Japan since March 2001, which led to an unprecedented high level of current account balances, may have provided ample reserves to the financial sector. However, such a measure was not promptly transmitted into the expansion of lend- 
ing and broad money (M2 + CDs) enough to stimulate the economy and to reverse lowered stock market liquidity. ${ }^{8}$

Since interest rates cannot fall below zero, whether or not the monetary authorities can provide an additional stimulus to the economy remains in question. Securities investors sufficiently averse to liquidity risk may avoid holding potentially illiquid stocks even at zero interest rates. However, if securities firms or other market makers are facing credit constraints due to problems in the banking sector, the direct provision of short-term loans to securities companies or securities finance companies may enhance stock market liquidity. Direct purchasing of the bills of financial institutions is one of the monetary-policy instruments available to the Bank of Japan (see Bank of Japan 2002). It has long been recognized that providing liquidity to financial markets during panics is an important part of central bank management. In the environment faced by Japan over the last decade, with a persistently illiquid market buffeted by volatile liquidity shocks, a more systematic provision of liquidity to equity markets may offer substantial benefits. Though systematically providing liquidity to the stock market may not overcome all of the risks faced by firms with illiquid balance sheets, enhancing stock market liquidity and reducing liquidity risk faced by investors could reduce the cost of equity capital in future fund raising (see, e.g., Lerner and Schoar 2004) and promote firm-level growth. However, it should be cautioned that a commitment to providing liquidity to financial markets on a permanent basis may have an inflationary bias in the long run.

\section{Appendix}

\section{Stock Market Data}

Data on individual firms' returns are from the PACAP (Pacific Capital Markets) database. For each share in our sample, we use daily returns without dividends reinvested (PACAP mnemonic: DRETND) and trading values (TRDVAL). Daily returns are daily equally weighted market returns without cash dividends reinvested (DERMND). We also use (TRDVAL) monthly data on trading values and market capitalization (MKTCAP). We also use a PACAP monthly return, which is monthly equally weighted market returns without cash dividends reinvested (MERMND). Turnover

8. The intermediary functions of the money market declined at the extremely low interest rate. With the quantitative easing policy, financial institutions-including banks, securities companies, and securities finance companies - have accumulated rapidly current account balances with the Bank of Japan. Despite the resulting large increases in monetary base, however, financial intermediation was not revived because financial institutions built up the unprecedented level of excess reserves (see Hetzel 2004). 
Table 8A.1

\begin{tabular}{lr|lr}
\hline Agriculture and forestry & 1 & Nonferrous metals & 20 \\
Air transportation & 3 & Other manufacturing & 24 \\
Chemicals & 107 & Petroleum & 6 \\
Communications & 1 & Precision equipment & 18 \\
Construction & 75 & Pulp and paper & 12 \\
Electric machinery & 99 & Real estate & 15 \\
Electric power and gas & 14 & Retail & 39 \\
Financial (non bank \& securities) & 10 & Rubber & 8 \\
Fishery & 5 & Services & 22 \\
Foods & 51 & Shipping & 8 \\
Glass and ceramics & 21 & Textiles & 34 \\
Iron and steel & 30 & Transportation equipment & 56 \\
Land transportation & 22 & Warehousing and wharfing & 7 \\
Machinery & 56 & Wholesale & 43 \\
Metal products & 13 & Total & 828 \\
Mining & 8 & & \\
\hline
\end{tabular}

and market capitalization in the stocks in the Tokyo Stock Exchange Topix Index are from CEIC DRI Asia Database.

\section{Cross-Sectional Data}

To construct cross-sectional data on firms, we use data from a PACAP database on balance sheets that contains our main measure of firm size and normalization variable on Total Assets (PACAP mnemonic: BAL22). Short-term loans to asset ratio is the sum of accounts and notes payable (BAL10) and short-term loans (BAL11) divided by total assets. Other liabilities to asset ratio is total liabilities (BAL17) divided by total assets minus short-term loans to asset ratio. We measure liquid assets to assets ratio is the sum of cash (BAL1) and marketable securities (BAL2) divided by total assets. Financial to book value is the sum of total liabilities and the product of number of shares of common stock (MKT5) and share price (MKT3) divided by total assets. Return on equity is net income (INC9) divided by total shareholder's equity (BAL21). We construct percentage of stocks held by banks or corporate sector as the number of shares owned by government and local government (JAF75) plus the number of shares owned by financial institutions (JAF76) plus the number of shares owned by other business corporations (JAF78) divided by total shares owned (JAF81). We also measure growth in net fixed assets (BAL7) and sales (INC1).

Industry-level dummy variables are also created to match the industries in table 8A.1.

\section{Time-Series Data}

Time-series data are obtained from the OECD Main Economics Indicators. 
topix: The Tokyo Stock Exchange Topix Index

cpi: CPI Services Less Housing $(1995=100)$

$m 2:$ M2 plus CD (trillions of yen, seasonally adjusted)

Additional data are obtained from the CEIC DRI Asia database.

$M B$ : Monetary Base (monthly average, billions of yen, seasonally adjusted with X-12)

$y$ : All Industry Activity Index $(1995=100$, seasonally adjusted with X-12) call: Uncollateralized Overnight Rate (\%)

\section{References}

Ahn, Hee-Joon, Jun Cai, Yasushi Hamao, and Richard Y. K. Ho. 2002. The components of the bid-ask spread in a limit-order market: Evidence from the Tokyo Stock Exchange. Journal of Empirical Finance 9 (November): 399-430.

Almeida, Heitor, Murillo Campello, and Michael S. Weisbach. 2004. The cash flow sensitivity of cash. Journal of Finance 59 (August): 1777-804.

Amihud, Yakov, and Haim Mendelson. 1986. Asset pricing and the bid-ask spread. Journal of Financial Economics 17 (December): 223-49.

Bank of Japan. 2002. Principal terms and conditions pertaining to the purchase of bills. Bank of Japan. Mimeo.

Bayoumi, Tamim. 2001. The morning after: Explaining the slowdown in Japanese growth in the 1990s. Journal of International Economics 53 (April): 241-59.

Campbell, John Y., Sanford J. Grossman, and Jiang Wang. 1993. Trading volume and serial correlation in stock returns. Quarterly Journal of Economics 108 (November): 905-39.

Chao, Chaoshin, and C. James Hueng. Forthcoming. Over-reaction effects independent of risk and characteristics: Evidence from the Japanese Stock Market. Journal of Japan and the World Economy, forthcoming.

Choi, Woon Gyu, and Yungsan Kim. 2001. Monetary policy and corporate liquid asset demand. IMF Working Paper no. WP/01/177 Washington, DC: International Monetary Fund, November.

Chordia, Tarun, Richard Roll, and Avanidhar Subrahmanyam. 2002. Order imbalance, liquidity, and market returns. Journal of Financial Economics 65 (July): $111-30$.

Chordia, Tarun, Asani Sarkar, and Avanidhar Subrahmanyam. 2002. An empirical analysis of stock and bond market liquidity. Emory University Working Paper.

Forbes, Kristin. 2000. The Asian flu and Russian virus: Firm-level evidence on how crises are transmitted internationally. NBER Working Paper no. 7807. Cambridge, MA: National Bureau of Economic Research, July.

Hamao, Yasushi, Jianping Mei, and Yexiao Xu. 2003. Idiosyncratic risk and the creative destruction in Japan. NBER Working Paper no. 9642. Cambridge, MA: National Bureau of Economic Research, April.

Hetzel, Robert L. 2004. Price stability and Japanese monetary policy. IMES Discussion Paper No. 2004-E-6. Tokyo, Japan: Institute for Monetary and Economic Studies, Bank of Japan.

Hubbard, R. Glenn, Kenneth N. Kuttner, and Darius N. Palia. 2002. Are there bank effects in borrowers' costs of funds? Evidence from a matched sample of borrowers and banks. Journal of Business 75 (October): 559-81. 
Ito, Takatoshi. 1994. The Japanese economy. Cambridge, MA: The MIT Press.

Ito, Takatoshi, and Kimie Harada. 2000. Japan premium and stock prices: Two mirrors of Japanese banking crises. NBER Working Paper no. 7997. Cambridge, MA: National Bureau of Economic Research.

Kiyotaki, Nobuhiro, and John Moore. 2001. Liquidity, business cycles and monetary policy. London School of Economics. Mimeo.

Lerner, Josh, and Antoinette Schoar. 2004. The illiquidity puzzle: Theory and evidence from private equity. Journal of Financial Economics (April): 3-40.

Miyao, Ryuzo. 1996. Does a co-integrating M2 demand relation really exist in Japan? Journal of Japan and the International Economies 10 (June): 169-80.

. 2002. The effects of monetary policy in Japan. Journal of Money, Credit and Banking 34 (May): 376-92.

Nagayasu, Jun. 2003. A re-examination of the Japanese money demand function and structural shifts. Journal of Policy Modeling 25 (June): 359-75.

Opler, Tim C., Lee Pinkowitz, Rene Stultz, and Rohan Williamson. 1999. The determinants and implications of corporate cash holdings. Journal of Financial Economics 52 (April): 3-46.

Pastor, Lubos, and Robert F. Stambaugh. 2003. Liquidity risk and expected stock returns. Journal of Political Economy 111 (June): 642-85.

Persaud, Avinash. 2000. Sending the herd off the cliff edge: The disturbing interaction between herding and market-sensitive risk management practices. State Street. Mimeo.

Sekine, T. 1998. Financial liberalization, the wealth effect, and the demand for broad money in Japan. Bank of Japan Monetary and Economic Studies 16 (May): $35-55$.

Stahel, Christof W. 2004. Is there a global liquidity factor? Ohio State University. Mimeo.

Tokyo Stock Exchange. 2003. Tokyo Stock Exchange Handbook 2003. Tokyo.

Ueda, Kazuo. 1993. A comparative perspective on Japanese monetary policy: Shortrun monetary control and the transmission mechanism. In Japanese monetary policy, ed. Kenneth J. Singleton, 7-30. Chicago: University of Chicago Press.

Wang, Ashley W. 2003. Institutional equity flows, liquidity risk and asset pricing. University of California, Los Angeles. Mimeo.

\section{Comment Shin-ichi Fukuda}

This chapter investigates what impacts liquidity shocks had on micro and macroeconomy in Japan during the past decade. It has three major findings: (a) empirical evidence on liquidity shocks of Japanese stock markets based on daily data, (b) microevidence on the liquidity based on the firmlevel data, and (c) macroevidence based on time-series data. All of them are valuable empirical studies.

\section{Empirical Evidence on Liquidity Shocks Based on Daily Data}

The first important contribution of this chapter is on empirical evidence on liquidity shocks of Japanese stock markets. There are several previous 
studies that tried to measure the liquidity of stock markets. But there are relatively few for Japanese stock markets. The analytical method follows Pastor and Stambaugh (JPE 2003). It estimates the parameter that measures the degree to which sales affect expected returns, and supposes that the parameter measures "liquidity." The intuition is that "order flow" should be accompanied by a return that one expects to be partially reversed in the future if the stock is not perfectly liquid. The greater the expected reversal for a given dollar volume, the lower the stock's liquidity.

By using the data of Japanese stock markets in the post-bubble period, the authors find steep drops in the liquidity and steep rises in liquidity risk. There was a clear-cut relationship between liquidity shocks and stock returns. In particular, most of liquidity shocks occurred during market downturns. The results are very reasonable. However, as for the relationship between liquidity shocks and stock returns, their causality is not clear.

The chapter reports three subperiods that had steep drops in the liquidity and steep rises in liquidity risk: 1991-1992 (the period after the crush of the bubbles), 1997-1998 (the period of banking crisis in Japan), and 20002002 (the deflation period). Liquidity shocks might have caused the market downturns during these periods. It is, however, possible that the market downturns in turn caused liquidity shocks during these periods. To identify the causality, we need to check which events caused the "liquidity shocks" observed in the chapter. Checking which events caused some spikes of the "liquidity shocks" may verify the causality.

\section{Microevidence on the Liquidity Based on the Firm-Level Data}

The second important contribution of this chapter is on microevidence on the liquidity shocks based on the firm-level data in Japan. In previous literature, Hasbrouck and Seppi (JFE 2001) find that idiosyncratic liquidity strongly dominates the common liquidity factor in explaining returns by using the Dow Jones Index. But few previous studies explored how cross-sectional variations of "liquidity" are related to firms' characteristics, such as their balance sheets. The chapter thus clearly provides a new empirical evidence by using the microdata in Japan from 1995 to 2001.

The chapter reports various cross-sectional variations of "liquidity" in Japanese stock markets. In particular, it showed that firms with high exposures to liquidity shocks are those whose balance sheets are illiquid, that is, high short-term debt-asset ratio and low liquid assets to asset ratio, and that large firms (in terms of assets) have less exposure to liquidity shocks than small firms. The findings are interesting. Their intuitive interpretations are, however, not necessarily straightforward.

The interpretations in the chapter are as follows. If a firm has more liquid assets, it will be less exposed to liquidity shocks. Financially weak firms will fear financial strains caused by insufficient reserves of liquidity. The interpretations look similar to those of agency cost approaches. However, 
"liquidity" in the chapter is "liquidity" for investors in the stock markets. The "liquidity" in the stock markets is different from "liquidity" of firms' balance sheets. We thus need a new story to explain why "liquidity" in the stock markets is so related to "liquidity" of firms' balance sheets.

"Liquidity" in the stock markets is liquidity for outside investors. We thus need to explain why those investors could not diversify idiosyncratic liquidity shocks. My interpretations of the results are as follows. "Liquidity" in the stock markets may be related with some default risk of firms. The stocks become more illiquid for the firms that have higher default risk. Default risk varies across firms. Firms whose balance sheets are illiquid (that is, firms with high short-term debt-asset ratios and small liquid assets) tend to face larger default risk. Large firms face smaller default risk than small firms. The interpretations seem consistent with empirical results in the chapter. But if this is the case, default risk rather than "liquidity" in the stock markets is the ultimate source that explains cross-sectional variations of "liquidity." The implications will be different.

On microevidence on the liquidity based on the firm-level data, the chapter provides other interesting findings: (a) Firms that have high liquidity exposure have slower capital investment; (b) Liquidity exposure is also an important determinant of sales growth. But in explaining capital investment, some important variables such as Tobin's $q$ and profits are missing in the regressions. Thus, their interpretations may not be easy. There are two types of liquidity: (a) "liquidity" in the stock markets that reflect liquidity for outside investors and (b) "liquidity" of firms' balance sheets. The results seem to suggest that the first type is much more important than the second type for capital investment. They suggest that in Japan, there was no credit constraint in the sense of traditional agency cost approaches. However, it contradicts a large number of studies that support the importance of the second type of liquidity for capital investment. Liquidity exposure to the first type is highly correlated with that to the second. The regression has some missing variables and some measurement errors because it uses book values in the balance sheet rather than market values. It is very difficult to distinguish the effects of two types, although the regressions include proxies for both types of liquidity exposure.

\section{Macroevidence on the Effects of Liquidity Shocks Based on Time-Series Data}

The third important contribution of this chapter is on macro time-series evidence on the effects of liquidity shocks based on VARs. Several previous studies investigated how the liquidity measures of stock markets affect several variables in the stock markets. But there are few studies that investigated how the liquidity measures of stock markets affect macrovariables.

The paper provides the times-series analysis (that is, VARs and impulseresponse functions) based on monthly (and quarterly) macrodata. The 
sample period is from 1990 to 2001. It shows that liquidity shocks have significant impacts not only on stock returns, but also on various macrovariables and monetary variables. On the impacts of a negative liquidity shock on macrovariables, it finds negative impacts on CPI, positive impacts on unemployment rate, negative but insignificant impacts on IIP, and negative impacts on changes of business investment. Except for IIP, the impacts are large and persistent. But the impacts seem to be too big and too persistent. For example, liquidity shocks explain 25 percent of the variation in CPI and unemployment rate. It is hard to believe that the shocks can explain such a large proportion of variations.

Why did we have such big impacts of liquidity shocks on macro and monetary variables? A possible reason is that only limited variables are included in VARs. If some key variables are missing, the third factors may cause spurious impacts of liquidity shocks on macro and monetary variables. In particular, many of the macro and monetary variables have some sluggishness. Even after exogenous shocks occurred, these variables take time to adjust. Stock prices and liquidity shocks, in contrast, respond to the exogenous shocks almost instantaneously. If this is the case, liquidity shocks can cause macro and monetary variables in the sense of Granger. But it does not necessarily mean that liquidity shocks affect macro and monetary variables.

\section{What Policy Implications?}

Overall, the chapter provides various interesting empirical findings. These findings imply that liquidity exposure is an important source of economic downturns in Japan. The results deserve publication by themselves. But the chapter's policy implications are not necessarily clear. Could Japan improve macro- and micro-level economic downturns by eliminating liquidity exposure? If yes, how?

In the paper, illiquid balance sheets of the firms explain a part of microlevel liquidity shocks. But its explanatory power was very small (that is, $R^{2}$ was 0.16 ). In conclusion, the chapter seems to suggest that lowering interest rates can eliminate macrolevel liquidity exposure. But the impulseresponse functions show almost negligible impacts from monetary shocks to liquidity shocks. At least the present version of the chapter did not explain major sources of highly illiquid equity markets during the recent deflationary period. The ultimate source of economic downturns in Japan seems to be left unexplained in the chapter.

\section{References}

Hasbrouck, J., and D. Seppi. 2001. Common factors in prices, order flows, and liquidity. Journal of Financial Economics 59 (3): 383-411.

Pastor, L., and R. F. Stambaugh. 2003. Liquidity risk and expected stock returns. Journal of Political Economy 111 (3): 642-85. 


\section{Comment Makoto Saito}

This chapter first applies a method proposed by Pastor and Stambaugh (2003) to daily Japanese stock data, and constructs the time-series of degrees of market liquidity as state variables for asset pricing. Then, using this measure of market liquidity, it estimates liquidity betas, or risks associated with changes in market liquidity for individual stocks. In addition, the authors conduct a cross-sectional analysis of effects of these estimated liquidity betas on performances of firms, as well as a time-series analysis of effects of aggregate market liquidity on macroeconomic variables.

Major findings of this chapter are summarized as follows. First, stock markets were extremely illiquid during the late 1990s. Second, firms with liquid balance sheets carried relatively low liquidity risks. Third, high liquidity risks were associated with low performances of firms. Fourth, aggregate liquidity measures served as a leading indicator for major aggregate variables such as output, investment, and employment.

Before commenting on this chapter, I would like to make a quick review of a method proposed by Pastor and Stambaugh (2003). They identify orderinduced one-day return reversals as market impacts from individual stock data, and construct an aggregate liquidity measure by averaging such market impacts over individual return reversals. Then, they estimate an individual liquidity beta by checking whether innovations on the above-constructed liquidity measures are priced for equity premiums of individual stocks.

To my best knowledge, this chapter is the first serious application of Pastor and Stambaugh (2003) to Japanese stock data. Sincere readers of this chapter might be intellectually curious to know how innovations in aggregate liquidity are priced in Japanese stock markets in comparison with U.S. stock markets. In this regard, reporting detailed information as to the estimated liquidity betas would be appreciated greatly by such readers.

I would like to discuss this chapter in two respects. My first comment concerns a theoretical relationship between aggregate liquidity in stock markets and macroeconomic variables. This paper well documents that negative shocks on aggregate liquidity measures are followed by declines in macroeconomic activities. Then, one may want to ask which theoretical hypothesis may explain such a relationship between them. As mentioned above, Pastor and Stambaugh's liquidity measures are based on highfrequency phenomena such as one-day return reversals. In other words, the construction of this liquidity measure implicitly assumes that pricing distortion is fixed at least partially within one business day. With due consideration for this aspect, it would be rather hard to imagine that such highfrequency frictions themselves have direct and substantial impacts on macroeconomic activities. 
One possible story for the above relationship is that there is a common shock which drives both illiquidity of stock markets and economic slowdown. For example, due to downward revisions in expectations about economic fundamentals among market participants, stock markets would become seller-dominated, and market liquidity would be deteriorated to a large extent. Circumstantial evidence for this story is that during the financial crises in both 1997 and 1998, not only stock markets, but also other markets serving for corporate financing, were extremely illiquid.

My second comment regards responses of monetary policy to illiquid financial markets, which may have something to do with issues broadly raised by this conference. I still believe that a monetary policy is quite important in terms of maintaining orderly financial markets, though not controlling business cycles, when financial markets are extremely illiquid during financial crises. One important question is how a central bank should behave in order to recover market liquidity. Which financial market should the bank target? Which policy instrument should it adopt?

During a financial crisis, liquidity often shifts from stock markets or corporate bond markets, to money markets or government-bond markets. In particular, there may emerge extremely strong demand for short-run government-issued bonds. In such a case, the open-purchase operations in which a central bank provides liquidity to commercial banks that are major market makers at money markets, would not be as effective as they are in normal market conditions. Through monetary operations, the Bank of Japan might just yield an additional demand for money market instruments in competition with other private players.

One possible effective operation may be to provide liquidity to security companies and investment banks that are major market makers at stocks and corporate bonds, or even more directly to large investors that hold long positions in stock markets by carrying short positions in money markets. A central bank's direct purchase of corporate stocks may be an alternative choice. Given the authors' empirical finding that stock markets were extremely illiquid during the financial crises in the late 1990s, discussing possible policy measures to recover market liquidity in more detail would enhance the value of this chapter substantially.

\section{Reference}

Pastor, Lubos, and Robert F. Stambaugh. 2003. Liquidity risk and expected stock returns. Journal of Political Economy 111 (3): 642-85. 